Somar, L. 2001. Kambuh, Relapse. Sudut pandang bagi mantan pecandu narkoba. Jakarta : Penerbit PT Gramedia Widiasarana bekerjasama dengan Yayasan Kasih Mulia.

Szapocznik, J., Perez-Vidal, A., Brickman, A., Foote, F., Santisteban, D., Hervis, O., \& Kurtines, W. 1988. Engaging adolescent drug abusers and their families into treatment : A strategic structure systems approach. Journal of Consulting \& Clinical Psychology, 56. 552-557.

Todd, T.C. 1988. Treating families with a chemically dependent member. Dalam Nunnaly , E.W., Chilman, C.S., \& Cox, F.M. (Eds.). Mental Illness, Delinquency, Addictions and Neglect : Families in Trouble Series. Vol. 4. Newbury Park: Sage Publications.

Westermeyer, J. 1997. Substance -related disorders. Dalam Ammerman, R.T \& Hersen, M. (Eds.). Handbook of Prevention and Treatment with Children and Adolescents : Intervention in The Real World Context. New York : John Wiley \& Sons, Inc.

Wills, T.A., Brody, G.H., Gibbons, F.X. , \& Gerrard, M. 2000. Protection and vulnerability processes relevant for early onset of substance use : a test among African American children. Health Psychology, 19. 253 - 263.

\section{MODEL PENILAIAN TRANSAKSI \\ PIHAK BERELASI YANG TERINDIKASI TUNNELING: BUKTI EMPIRIS PADA TRANSAKSI PIHAK \\ BERELASI DI INDONESIA}

Oleh:

Ratna Candra Sari

Universitas Negeri Yogyakarta

Email: chan_sari@yahoo.com

\begin{abstract}
This study focuses on the expropriation of non-controlling shareholders through tunneling activity. Current study in tunneling still found obstacles in measurement because it is difficult to prove, although tunneling activity going on in business practices. The objective of this is to develop tunneling valuation model. This study defines the tunneling as related party transactions that are used to tunnel out of public companies' resource for the benefit of the controlling shareholder. Tunneling in this study was divided based on the resources being tunneled that are cash flow tunneling and asset tunneling.

The formation a valuation model using data of disclosure of statements affiliate and conflict of interest transactions 20102011. Based on the assessment method of tunneling, the transaction is classified as cash flow tunneling as $40.5 \%$ and asset tunneling as 34\%. The company which announced related party transaction which indicated tunneling obtain negative abnormal return during the announcement of the related party transaction.
\end{abstract}

Keywords: tunneling, transaksi pihak berelasi 


\section{PENDAHULUAN}

Masalah keagenan merupakan salah satu isu sentral dalam literatur keuangan. Pada perusahaan dengan kepemilikan terkonsentrasi, pemegang saham dapat mengendalikan manajemen atau bahkan menjadi bagian dari manajemen itu sendiri. Masalah keagenan yang menonjol dalam perusahaan seperti ini adalah konflik kepentingan antara pemegang saham pengendali dan pemegang saham nonpengendali. Pemegang saham pengendali dapat melakukan ekspropriasi ${ }^{1}$ pada pemegang saham nonpengendali dengan berbagai cara. Gilson dan Gordon (2003) mengidentifikasi dua kemungkinan cara yang dapat dilakukan pemegang saham pengendali untuk mendapatkan manfaat privat atas kontrol dari kebijakan perusahaan yaitu melalui kebijakan operasi perusahaan dan kebijakan kontraktual dengan pihak lain. Bentuk-bentuk manfaat privat yang dapat diperoleh melalui kebijakan operasi perusahaan antara lain gaji dan tunjangan tinggi, bonus dan kompensasi besar, serta dividen. Sedangkan cara untuk memperoleh manfaat privat melalui kebijakan kontraktual antara lain dilakukan melalui tunneling. Johnson et al. (2000a) mendefinisikan tunneling sebagai transfer sumber daya keluar dari perusahaan untuk kepentingan pemegang saham pengendali.

Penelitian ini berfokus pada ekspropriasi terhadap pemegang saham nonpengendali melalui aktivitas tunneling. Penelitian tunneling saat ini masih menemukan kendala dalam hal pengukuran karena aktivitas tunneling sulit dibuktikan meskipun terjadi dalam praktik bisnis. Tidaklah mengherankan apabila sebagian besar penelitian terdahulu tentang tunneling berfokus pada pengujian reaksi pasar pada saat pengumuman transaksi pihak berelasi (Bae et al., 2001; Facio dan Stollin, 2006; Cheung et al., 2006; Cheung et al., 2009a).

\footnotetext{
${ }^{1}$ Ekspropriasi (expropriation) adalah proses penggunaan kontrol untuk memaksimalkan kesejahteraan sendiri dari distribusi kekayaan pihak lain (Claessens et al., 2000b)
}

Berikut ini adalah ilustrasi transaksi pihak berelasi yang digunakan untuk tunneling yang mengakibatkan penurunan kinerja keuangan perusahaan yang di-tunnel. Perusahaan publik di Indonesia yaitu $\mathrm{MI}^{2}$ terindikasi melakukan aktivitas tunneling dalam bentuk manipulasi harga jual batubara oleh KC. KC menggunakan special purpose company yaitu RL yang berada di Cayman Island untuk melakukan transfer keuntungan. Berikut ini adalah struktur kepemilikan perusahaan:

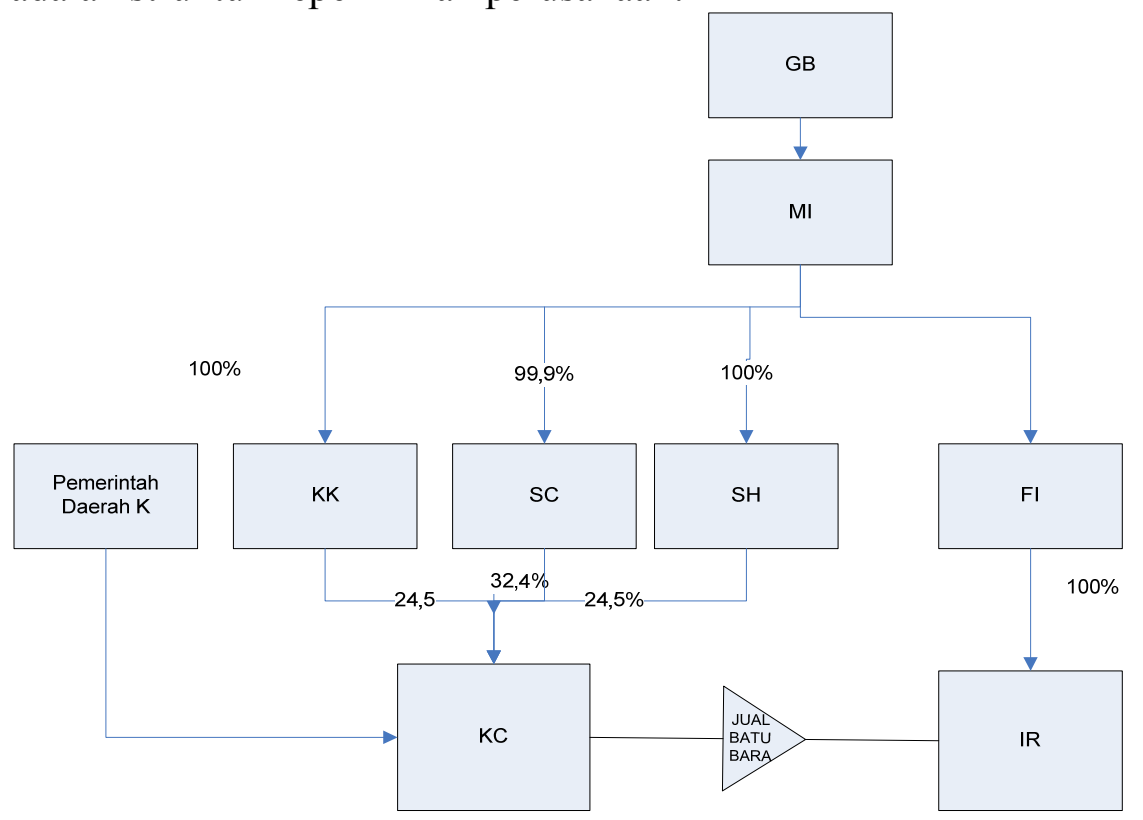

Gambar 1. Struktur Kepemilikan MI

KC dan RL merupakan anak perusahaan MI. GB merupakan pemilik ultimat PT MI. KC tidak menjual batubara secara langsung kepada pembeli potensial, tetapi menjualnya melalui RL. Batubara dijual kepada RL di bawah harga wajar, hal

$\overline{{ }^{2} \text { Penggunaan kode untuk alasan etis }}$ 
ini menyebabkan laba KC menurun. Kemudian, RL menjual kembali batubara pada harga pasar, sehingga laba RL meningkat. KC merupakan perusahaan yang di-tunnel ${ }^{3}$ karena penjualan batubara di bawah harga wajar kepada RL menyebabkan berpindahnya laba KC kepada pemegang saham pengendali. Pemegang saham nonpengendali $\mathrm{KC}$ yaitu pemerintah daerah $\mathrm{K}$ dirugikan akibat transaksi tersebut, sedangkan pemegang saham pengendali (GB) secara keseluruhan diuntungkan karena kerugian di $\mathrm{KC}$ dapat tertutup oleh keuntungan yang diperoleh dari RL. Transaksi tersebut tergolong sebagai cash flow tunneling karena (1) transaksi tersebut menyebabkan transfer sumber daya berupa aset lancar keluar perusahaan, (2) transaksi tersebut menguntungkan pemegang saham pengendali dengan mengorbankan kepentingan pemegang saham non pengendali. Transaksi cash flow tunneling tersebut juga merupakan upaya penghindaran beban pajak secara substansial dengan cara men-tunnel keuntungan dari Indonesia ke Cayman Island yang merupakan negara tax heaven. Motivasi pemegang saham pengendali untuk memindahkan keuntungan dari KC ke RL karena hak aliran $\mathrm{kas}^{4}$ di RL lebih besar dibanding hak aliran kas di KC.

Keterbatasan informasi dan regulasi mengenai transaksi pihak berelasi menyebabkan kesulitan bagi pengguna laporan keuangan untuk menilai apakah transaksi pihak berelasi dilakukan untuk tujuan ekonomi atau oportunis ${ }^{5}$. Oleh karena itu, isu pokok

\footnotetext{
${ }^{3}$ Meskipun merupakan perusahaan yang di-tunnel, KPC tidak masuk dalam sampel penelitian karena bukan merupakan perusahaan publik.

${ }^{4}$ Hak aliran kas adalah klaim keuangan pemegang saham terhadap perusahaan (La Porta et al., 1999).

${ }^{5}$ Terdapat tiga motivasi utama perusahaan melakukan transaksi pihak berelasi: Pertama, transaksi pihak berelasi digunakan untuk meminimalkan biaya transaksi (Cook, 1977 dan Fisman dan Khanna, 1998). Motivasi kategori pertama merupakan motivasi ekonomi. Kedua, transaksi pihak berelasi dapat digunakan untuk memanipulasi laba (Jian dan Wong, 2003; Aharony et al, 2009). Ketiga, transaksi pihak berelasi digunakan untuk tujuan tunneling 94
}

dalam penelitian ini berkaitan dengan model penilaian tunneling. Model penilaian tunneling bertujuan untuk menilai transaksi berelasi yang terindikasi untuk melakukan tunneling.

Saat ini belum ada model untuk menilai transaksi berelasi yang kemungkinan besar menjadi merupakan tunneling dan yang tidak. Ketiadaan model penilaian menyebabkan tingginya risiko yang dihadapi khususnya oleh pemegang saham non-pengendali, karena berdasarkan bukti empiris tunneling akan menyebabkan penurunan nilai perusahaan. Oleh karena itu, penelitian bertujuan membangun model penilaian tunneling.

Gilson dan Gordon (2003) mengidentifikasi dua cara yang dilakukan pemegang saham pengendali untuk mendapatkan manfaat privat atas kontrol melalui kebijakan perusahaan, yaitu:

1. Pemegang saham pengendali dapat memperoleh manfaat privat atas kontrol dari kebijakan operasi perusahaan. Bentuk-bentuk manfaat privat seperti ini meliputi gaji dan tunjangan tinggi, bonus dan kompensasi besar, dividen yang tidak dibagi agar perusahaan memiliki banyak sumber daya yang dapat diekspropriasi oleh pemegang saham pengendali, dan lain-lain.

2. Pemegang saham pengendali dapat memperoleh manfaat privat melalui kebijakan kontraktual dengan pihak lain. Bentukbentuk manfaat privat seperti ini antara lain dilakukan melalui: transfer pricing yang lebih murah kepada perusahaan pengendali, penjualan aset yang lebih murah dari harga pasar kepada pemegang saham pengendali, dan freezing out yaitu menjual saham perusahaan kepada pihak lain yang juga terkait dengan pemegang saham pengendali dengan harga lebih murah dari harga pasar.

Terdapat dua cara pengukuran ekspropriasi yaitu:

1. Langsung

(Cheung et al., 2009a; Cheung et al., 2009b, Cheung et al., 2006). Motivas kedua dan ketiga merupakan motivasi oportunis. 
Metode ini mengukur secara langsung tindakan pemegang saham pengendali yang berpengaruh pada penurunan nilai perusahaan yang ditanggung pemegang saham nonpengendali. Salah satu metode pengukuran langsung yaitu transaksi antara perusahaan publik dengan pihak berelasi. Transaksi pihak berelasi dapat digunakan sebagai channel untuk melakukan transfer sumber daya keluar perusahaan untuk kepentingan pemegang saham pengendali. Cheung et al. (2006) membagi transaksi pihak berelasi ke dalam tiga kategori yaitu: (1) transaksi yang merupakan ekspropriasi, (2) transaksi yang menguntungkan perusahaan publik dan (3) transaksi yang didorong oleh alasan strategis. Tabel 1 berikut menunjukkan kategorisasi tersebut:

\section{Tabel 1}

Kategori Transaksi antar Pihak Berelasi

\begin{tabular}{|l|l|}
\hline $\begin{array}{c}\text { Tipe transaksi antar } \\
\text { pihak berelasi }\end{array}$ & \multicolumn{1}{|c|}{ Deskripsi } \\
\hline $\begin{array}{l}\text { A. Transaksi yang mempunyai kemungkinan menghasilkan } \\
\text { ekspropriasi pemegang saham nonpengendali }\end{array}$ \\
\hline Pembelian asset & $\begin{array}{l}\text { Transaksi pembelian aset berwujud/tidak } \\
\text { berwujud oleh perusahaan go publik dari } \\
\text { pihak berelasi atau dari perusahaan privat } \\
\text { yang dikontrol oleh pihak tersebut. }\end{array}$ \\
\hline Penjualan asset & $\begin{array}{l}\text { Transaksi penjualan aset berwujud/tidak } \\
\text { berwujud oleh perusahaan publik pada } \\
\text { pihak berelasi atau pada perusahaan privat } \\
\text { yang dikontrol oleh pihak tersebut }\end{array}$ \\
\hline Penjualan ekuitas & $\begin{array}{l}\text { Transaksi yang meliputi penjualan saham } \\
\text { perusahaan pada pihak berelasi atau } \\
\text { perusahaan privat yang dikontrol oleh pihak } \\
\text { tersebut }\end{array}$ \\
\hline $\begin{array}{l}\text { Hubungan } \\
\text { perdagangan }\end{array}$ & $\begin{array}{l}\text { Transaksi yang meliputi perdagangan } \\
\text { barang dan jasa antara perusahaan publik }\end{array}$ \\
\hline
\end{tabular}

\begin{tabular}{|c|c|}
\hline & $\begin{array}{l}\text { dan pihak berelasi atau perusahaan privat } \\
\text { yang dikontrol oleh pihak tersebut. }\end{array}$ \\
\hline Pembayaran kas & $\begin{array}{l}\text { Transaksi yang meliputi pembayaran kas } \\
\text { langsung oleh perusahaan publik pada } \\
\text { pihak berelasi atau perusahaan privat yang } \\
\text { dikontrol oleh pihak tersebut atau kepada } \\
\text { anak perusahaan. Contoh transaksi } \\
\text { pembayaran kas yaitu pemberian pinjaman } \\
\text { atau jaminan kas oleh perusahaan publik } \\
\text { untuk utang yang dimiliki oleh pihak berelasi } \\
\text { atau perusahaan privat yang dikontrol oleh } \\
\text { pihak tersebut. }\end{array}$ \\
\hline $\begin{array}{l}\text { B. Transaksi yang } \\
\text { nonpengendali }\end{array}$ & menguntungkan pemegang saham \\
\hline Penerimaan kas & $\begin{array}{l}\text { Transaksi yang melibatkan penerimaan kas } \\
\text { atau pinjaman yang disediakan oleh pihak } \\
\text { berelasi pada perusahaan go publik. }\end{array}$ \\
\hline $\begin{array}{l}\text { Subsidiary } \\
\text { relationship }\end{array}$ & $\begin{array}{l}\text { Transaksi antara perusahaan go publik dan } \\
\text { anak perusahaannya, meliputi akuisisi dan } \\
\text { penjualan saham atau aset dan transaksi } \\
\text { perdagangan. }\end{array}$ \\
\hline
\end{tabular}

C. Transaksi yang didorong oleh alasan strategis dan bukan merupakan ekspropriasi

Takeover offers dan Ketika perusahaan go publik menerima

joint ventures $\quad$ tawaran takeover oleh perusahaan go publik

lain dan ketika perusahaan go publik

membentuk joint venture atau strategic alliance dengan perusahaan lain yang telah mempunyai saham di perusahaan publik.

Sumber: Cheung et al., 2006

2. Tidak Langsung

Metode ini menggunakan proksi untuk mengukur tingkat ekspropriasi. Beberapa metode tidak langsung antara lain: 
a. Sistem legal sebagai proksi untuk kemungkinan ekspropriasi (La Porta et al., 1998; 2000b: Djankov et al., 2008). Sistem legal berpengaruh pada kebijakan dividen (La porta et al., 2000a) dan firm valuation (La porta et al., 2002).

b. Deviasi hak aliran kas dari hak kontrol sebagai proksi kemungkinan terjadinya ekspropriasi. Claessens et al. (2002a) menemukan bahwa market to book ratio berhubungan positif dengan hak aliran kas yang dipegang oleh pemegang saham pengendali (konsisten dengan incentive effect), tetapi berhubungan negatif dengan penyimpangan antara hak aliran kas dan hak aliran kontrol (konsisten dengan entrenchment effect). Deviasi hak aliran kas dari hak kontrol berpengaruh pada kebijakan dividen (Facio et al., 2001), firm valuation (Claessens et al., 2002b; Lemmon and Lins, 2003; Baek et al., 2004).

c. Earnings shock. Bertrand et al. (2002) menguji aktivitas tunneling dengan menelusuri penyebaran earnings shock dari grup perusahaan hak aliran kas rendah ke perusahaan hak aliran kas tinggi. Bertrand et al. (2002) menemukan bahwa penyebaran earnings dilakukan menggunakan item laba non operasi seperti laba/rugi pos luar biasa. Hal tersebut menunjukkan bahwa tunneling merupakan hasil dari transfer aset bukan dari transfer pricing. Hasil penelitian tersebut menunjukkan bahwa perusahaan yang sedikit melakukan tunneled away, diperdagangkan pada market to book ratio yang tinggi.

Johnson et al. (2000a) mendefinisikan tunneling sebagai transfer aset dan keuntungan keluar dari perusahaan untuk kepentingan pemegang saham mayoritas. Atasanov et al. (2008) membagi tunneling berdasarkan sumber daya yang di-tunnel yaitu:

a. Cash flow tunneling. Cash flow tunneling adalah transaksi yang mengalihkan kas dan aset lancar dari perusahaan kepada pemegang saham pengendali. Karakteristik cash flow tunneling:

b. Asset tunneling. Asset tunneling yaitu transfer aset berwujud/tidak berwujud dari perusahaan publik kepada pemegang saham pengendali, atau sebaliknya.

c. Equity tunneling. Equity tunneling adalah peningkatan kepemilikan pemegang saham pengendali pada perusahaan dengan mengorbankan pemegang saham nonpengendali.

\section{CARA PENELITIAN}

Pembentukan model penilaian tunneling dilakukan untuk identifikasi transaksi pihak berelasi yang merupakan tunneling dan yang tidak. Data diperoleh dari laporan keterbukaan informasi transaksi afiliasi dan benturan kepentingan perusahaan sektor rill yang diperoleh dari BAPEPAM dan LK. Laporan tersebut memuat secara rinci mengenai transaksi afiliasi dan benturan kepentingan antara lain mengenai obyek transaksi, nilai transaksi, tanggal transaksi, tanggal pengumuman, keterangan mengenai hubungan dengan pihak afiliasi dan laporan dari kantor penilai, sehingga pengungkapan mengenai transaksi tersebut dapat digunakan untuk membangun model penilaian tunneling. Data harga saham harian diperoleh dari Data Realtime Investment (RTI) di Program MSI dan Doktor FEB UGM.

Model penilaian tunneling adalah identifikasi transaksi pihak berelasi yang merupakan tunneling dan yang tidak. Transaksi pihak berelasi dikategorikan sebagai tunneling jika mempunyai karakteristik berikut:

1. Abnormal return negatif pada saat pengumuman transaksi berelasi. Penelitian Cheung et al. (2006) dan Cheung et al. (2009b) menunjukkan perusahaan mengalami return negatif pada saat pengumuman transaksi berelasi yang dikategorikan sebagai tunneling. Abnormal return adalah selisih antara return 
sesungguhnya dan return ekspektasi, rumus return abnormal sebagai berikut:

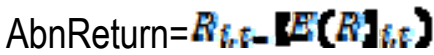

Return ekspektasi menggunakan mean-adjusted model, yaitu:

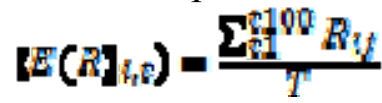

2. Transaksi berelasi masuk dalam kategori transaksi tunneling berdasarkan klasifikasi Cheung et al.(2006) dan Cheung et al. (2009b).

3. Terdapat overlapping owner yaitu kesamaan pemegang saham pengendali antara perusahaan dan pihak berelasi.

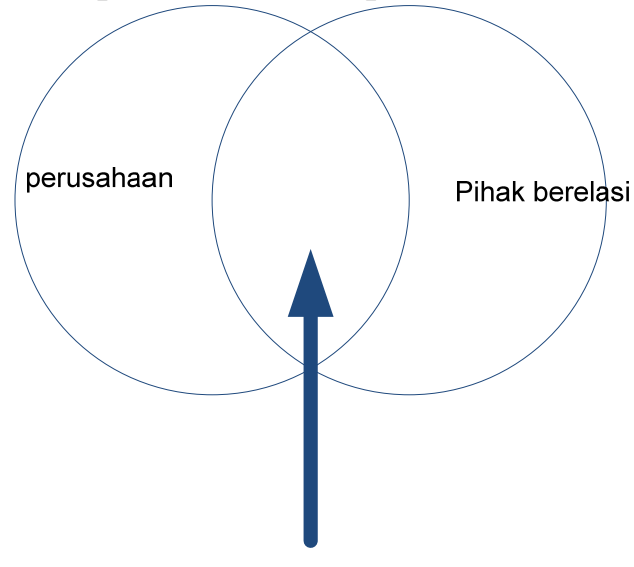

Overlapping owner

Gambar 2. Overlapping Owner

Goranova (2007) menemukan bahwa overlapping owner akan mentransfer sumber daya dari perusahaan hak aliran kas rendah ke perusahaan hak aliran kas tinggi. Beberapa kasus yang terindikasi tunneling seperti pada Kasus Coca Cola, SARL Peronnet dan Marcili juga terdapat overlap owner. Oleh karena itu, jika terdapat kesamaan pemegang saham pengendali antara perusahaan dan pihak berelasi, maka kecenderungan tunneling semakin tinggi.

4. Terdapat kesamaan direksi dan komisaris antara perusahaan dan perusahaan berelasi. Kesamaan personil manajemen kunci memberikan peluang adanya penggunaan kekuasaan untuk mengatur kebijakan keuangan maupun operasional perusahaan, sehingga memperoleh manfaat dari aktivitas tersebut. Beberapa kasus yang terindikasi tunneling seperti Kasus Coca Cola, SARL Peronnet dan Marcili juga terdapat kesamaan direksi dan komisaris.

5. Terdapat hubungan keluarga antara pihak-pihak yang melakukan transaksi.

6. Transaksi tersebut tidak dinilai oleh Kantor Jasa Penilai. Peraturan Bapepam-LK mewajibkan perusahaan untuk mengumumkan transaksi afiliasi dan benturan kepentingan kepada publik. Laporan tersebut harus memuat pendapat kewajaran transaksi dari Kantor Jasa Penilai. Transaksi yang tidak disertai laporan penilaian oleh Kantor Jasa Penilai, mempunyai indikasi digunakan sebagai tunneling karena tidak terdapat penilaian kewajaran transaksi.

Tabel 2 Berikut menunjukkan Metode Penilaian yang digunakan untuk mengkategorikan transaksi kedalam transaksi tunneling dan tidak.

Dasar pembobotan adalah variabel-variabel yang didasarkan pada ketegori data (data kuantitatif/kualitatif). Rumus berikut digunakan untuk menentukan skor transaksi tunneling atau tidak adalah:

skor Tumeling $=\frac{(k 1 * 30 \%+k 2 * 30 \%+k 3 * 10 \%+k 4 * 10 \%+k j * 10 \%+k 6 * 10 \%)}{100}$

Semakin tinggi rasio, semakin besar transaksi berelasi tersebut terindikasi sebagai tunneling. Cut off yang digunakan adalah 60, skor di atas 61 dikategorikan sebagai tunneling. 
Tabel 2

Metode Penilaian Tunneling

\begin{tabular}{|l|l|l|l|}
\hline No & \multicolumn{1}{|c|}{ Karakteristik } & \multicolumn{1}{|c|}{ Pengukuran } & Bobot \\
\hline K1 & $\begin{array}{l}\text { Terdapat Abnormal Return } \\
\text { negatif pada saat pengumuman } \\
\text { transaksi }\end{array}$ & $\begin{array}{l}\text { Nilai 1 untuk } \\
\text { abnormal return } \\
\text { negatif, nilai 0 } \\
\text { lainnya }\end{array}$ & $30 \%$ \\
\hline K2 & $\begin{array}{l}\text { Termasuk dalam transaksi } \\
\text { tunneling berdasarkan Cheung et } \\
\text { al. (2006) dan Cheung et al. } \\
(2009)\end{array}$ & $\begin{array}{l}\text { Variabel Dummy; 1 } \\
\text { untuk transaksi } \\
\text { kategori tunneling, 0 } \\
\text { lainnya }\end{array}$ & $30 \%$ \\
\hline K3 & $\begin{array}{l}\text { Terdapat } \text { overlapping } \text { owner } \\
\text { Kariabel Dummy; 1 } \\
\text { untuk ada, 0 lainnya }\end{array}$ & $10 \%$ \\
\hline K4 & $\begin{array}{l}\text { Terdapat kesamaan direksi dan } \\
\text { pemisaris antara perusahaan dan saham pengendali. }\end{array}$ & $\begin{array}{l}\text { Variabel Dummy; } 1 \\
\text { untuk ada, 0 lainnya }\end{array}$ & $10 \%$ \\
\hline K5 & $\begin{array}{l}\text { Terdapat hubungan keluarga } \\
\text { Kariabel Dummy; 1 } \\
\text { untuk ada, 0 lainnya }\end{array}$ & $10 \%$ \\
\hline K6 & $\begin{array}{l}\text { Penilaian transaksi oleh Kantor } \\
\text { Jasa Penilai }\end{array}$ & $\begin{array}{l}\text { Variabel Dummy; 1 } \\
\text { untuk ada, 0 lainnya }\end{array}$ & $10 \%$ \\
\hline
\end{tabular}

\section{PEMBAHASAN}

Berdasarkan metode penilaian tunneling, berikut ini adalah contoh transaksi yang terindikasi sebagai tunneling. Dalam contoh kasus tunneling, peneliti menggunakan kode (bukan menggunakan nama sesungguhnya) karena penilaian sebuah perusahaan yang ditunnel atau tidak didasarkan pada metode penilaian yang digunakan dalam penelitian ini. Meskipun dibangun berdasarkan kajian teoritis dan diskusi dengan pihak yang berwenang membuat regulasi dan akademisi, namun peneliti tidak melakukan konfirmasi dengan perusahaan yang bersangkutan. Oleh karena itu, peneliti menggunakan kode untuk alasan etis. Sebuah perusahaan publik di
Indonesia yaitu PT ED melalui DD melakukan transaksi dengan MM, keduanya mempunyai pemegang saham pengendali yang sama yaitu keluarga GQ. Berikut adalah gambar yang menunjukkan sifat transaksi berelasi antara PT ED/DD dengan MM.

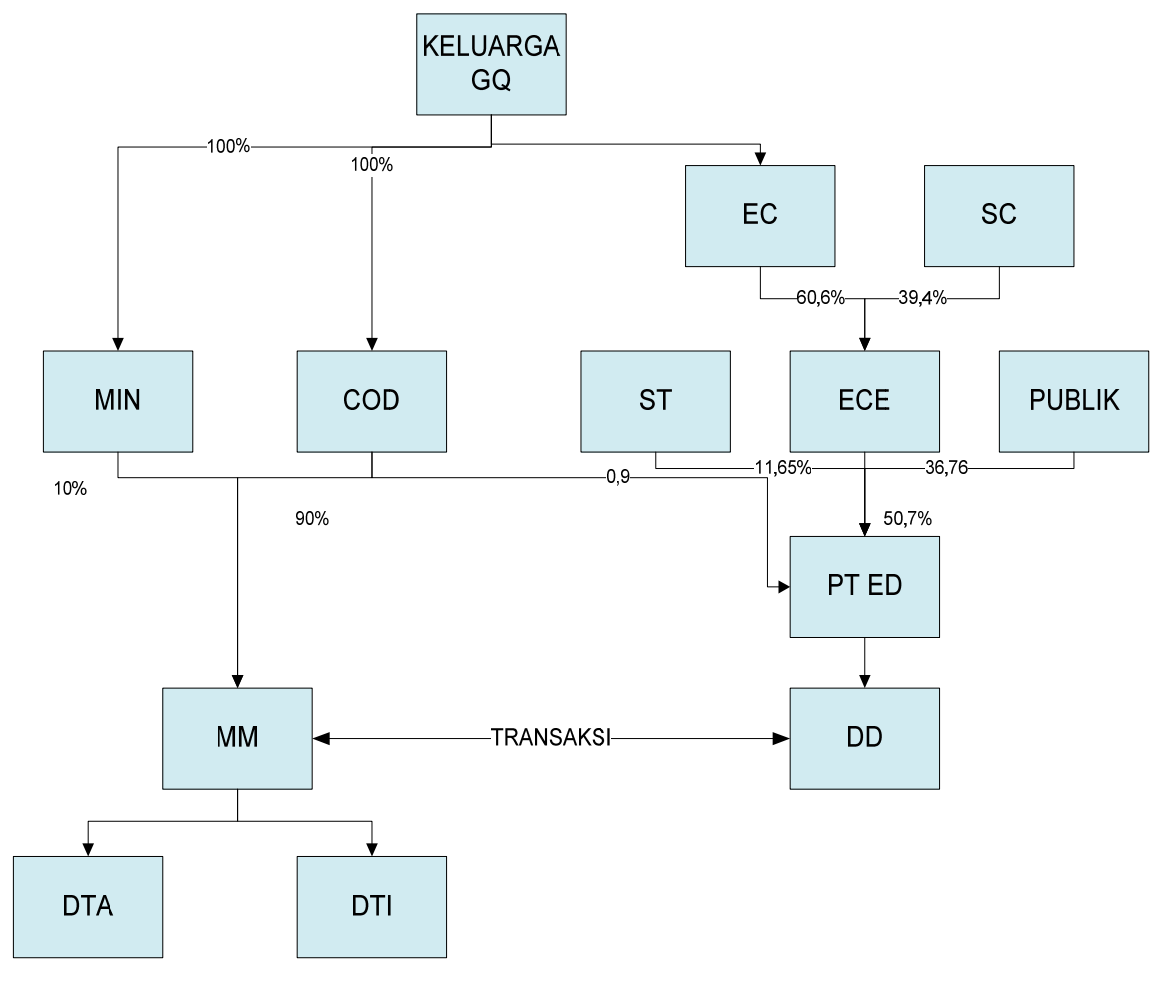

Gambar 3. Struktur kepemilikan PT ED

Selain dimiliki oleh pemegang saham pengendali yang sama, MM dan ED juga memiliki kesamaan komisaris dan direktur. Selain itu, komisaris dan direksi dijabat oleh anggota keluarga dari pemegang saham pengendali. 
Pada tanggal 26 Juni 2009, PT ED melalui anak perusahaannya (DD) telah menandatangani perjanjian jual beli dengan MM untuk membeli 99,9\% saham DTA dan 99,9\% saham DTI. PT ED juga melunasi seluruh utang DTA dan DTI kepada MM. Total transaksi jual beli dan subrogasi yang disepakati sejumlah US\$886.013. Sejumlah US\$75.122 digunakan untuk membeli saham DTA dan DTI dan US\$810.891 digunakan untuk pelunasan hutang DTA dan DTI kepada MM.

Keluarga GQ mempunyai total hak aliran kas di MM sebesar $100 \%$ sedangkan total hak aliran kas di PT ED sebesar $50,7 \%$. Hak aliran kas pemegang saham pengendali lebih besar di MM dibanding pada perusahaan publik PT ED, perbedaan hak aliran kas tersebut merupakan dorongan bagi perusahaan untuk men-tunnel sumber daya dari perusahaan hak aliran kas rendah (PT ED tbk) ke perusahaan hak aliran kas tinggi (MM).

PT ED dan MM/DTI/DTA merupakan pihak berelasi karena kedua entitas memiliki pengendalian bersama dan mempunyai kesamaan personel manajemen kunci. PT ED mengeluarkan kas sebesar US\$810.891 untuk pelunasan utang DTA dan DTI. Selain itu, PT ED mengeluarkan kas sebesar US\$75.122 untuk membeli DTI dan DTA meskipun DTI dan DTA mempunyai kinerja yang tidak baik. DTI adalah perusahaan yang mempunyai rugi bersih senilai (Rp5.257.128.705,) dan DTA mempunyai rugi bersih senilai (Rp734.908.351).

Transaksi PT ED dikategorikan sebagai transaksi yang terindikasi tunneling berdasarkan indikator:

1. Terdapat abnormal return negatif pada saat pengumuman transaksi sebesar $\quad-0,01079$. Penurunan nilai perusahaan tersebut menyebabkan kerugian pada perusahaan yang di-tunnel dan pemegang saham minoritas.

2. Cheung et al. (2009a) mengkategorikan transaksi pembayaran kas kepada pihak berelasi sebagai transaksi tunneling. Transaksi yang dilakukan PT ED tergolong sebagai transaksi pembayaran kas kepada pihak berelasi. PT ED mengeluarkan kas untuk membeli saham dan membayar utang DTI dan DTA kepada MM. PT ED membeli saham perusahaan yang mempunyai kinerja keuangan buruk dan mengalami kesulitan membayar utang pada MM. Transaksi tersebut secara keseluruhan menguntungkan pemegang saham pengendali karena aliran kas keluar dari PT ED, yang mana pemegang saham pengendali (GQ) mempunyai hak aliran kas rendah, mengalir ke MM, yang mana pemegang saham pengendali (GQ) memiliki hak aliran kas tinggi. Transaksi tersebut menyebabkan kerugian pada perusahaan publik (PT ED) dan pemegang saham non pengendali karena menyebabkan penurunan nilai perusahaan.

3. Terdapat overlapping owner. Perusahaan (PT ED) dan pihak berelasi (MM) dimiliki oleh pemilik yang sama yaitu keluarga GQ.

4. Terdapat kesamaan personel manajemen kunci.

Transaksi cash flow tunneling juga bisa dilakukan melalui pemberian piutang maupun penghapusan piutang pihak berelasi. Berikut ini adalah ilustrasi kasus yang terindikasi sebagai cash flow tunneling melalui penghapusan piutang pihak berelasi. Perusahaan publik dengan kode PT AI mempunyai piutang afiliasi kepada INC. INC merupakan perusahaan asosiasi yang dimiliki PT AI sebesar $50 \%$. Laporan Keuangan INC tidak dikonsolidasikan pada laporan keuangan PT AI. PT AI dan INC juga mempunyai kesamaan personel manajemen kunci, presiden komisaris INC merupakan presiden direktur di PT AI, presiden direktur INC merupakan direktur di PT AI, komisaris di INC juga merupakan komisaris di PT AI.

Piutang tersebut merupakan pinjaman modal kerja sehubungan dengan kesulitan keuangan yang dialami INC. PT AI memberikan piutang tanpa bunga, tanpa jaminan dan tidak ditentukan jangka waktu pembayarannya. Piutang diberikan sejak tahun 2005. Pada tanggal 11 November 2010 perusahaan 
mengumumkan penghapusan piutang tersebut. Pada sekitar tanggal pengumuman, perusahaan mengalami CAR negatif sebesar 0,006689. Berdasarkan metode penilaian tunneling, transaksi tersebut terindikasi tunneling dengan indikator yang digunakan:

1. Terdapat abnormal return negatif pada saat pengumuman transaksi sebesar $-0,006689$. Penurunan nilai perusahaan tersebut menyebabkan kerugian pada perusahaan dan pemegang saham non-pengendali.

2. PT AI dengan INC memiliki kesamaan komisaris dan direktur.

3. Transaksi berelasi yang dilakukan PT AI berupa penghapusan piutang pihak berelasi tergolong sebagai transaksi yang terindikasi tunneling berdasarkan penelitian Cheung et al. (2006).

Berdasarkan model penilain tunneling, skor transaksi tersebut adalah 80 sehingga dikategorikan sebagai transaksi yang terindikasi tunneling.

Tabel 3 adalah bukti bahwa transaksi berelasi yang terindikasi tunneling menurunkan nilai perusahaan. Perusahaan yang mengumumkan tipe transaksi berelasi tersebut memperoleh abnormal return (AR) negatif pada saat pengumuman transaksi berelasi untuk periode jendela $(-3,+3)$.

Secara rata-rata, selama periode jendela $(-3,+3)$, perusahaan yang melakukan transaksi yang terindikasi cash flow tunneling memperoleh mean adjusted return negatif. Penghapusan piutang berelasi memperoleh mean adjusted abnormal return negatif sebesar $-0,66 \%$, piutang berelasi memperoleh $-6,7 \%$, jaminan piutang berelasi memperoleh $-1,2 \%$, pembayaran jasa kepada pihak berelasi memperoleh $-6,6 \%$, sewa menyewa berelasi memperoleh $-3,1 \%$. Perusahaan yang melakukan transaksi yang terindikasi asset tunneling seperti pembelian aset dari pihak berelasi memperoleh $-3,7 \%$ dan perusahaan yang menjual aset kepada pihak berelasi memperoleh $-2,6 \%$. Perusahaan yang melakukan equity tunneling memperoleh mean adjusted return -
2,7\%. Sebaliknya, perusahaan yang melakukan transaksi yang tidak terindikasi tunneling, seperti penerimaan kas dari pihak berelasi dan transaksi dengan anak perusahaan yang dimiliki secara mayoritas memperoleh abnormal return positif sebesar $0,66 \%$.

Tabel 3

Cumulative abnormal return pada saat pengumuman transaksi berelasi tahun 2009-2010

\begin{tabular}{|c|c|}
\hline TRANSAKSI & $\begin{array}{c}\text { Mean Adusted, } \\
\text { hari }(-3,+3)\end{array}$ \\
\hline \multicolumn{2}{|l|}{ CASH FLOW TUNNELING : } \\
\hline 1 PENGHAPUSAN PIUTANG & $-0,00669$ \\
\hline PIUTANG & $-0,06755$ \\
\hline JAMINAN PIUTANG & $-0,01284$ \\
\hline PEMBAYARAN JASA & $-0,06601$ \\
\hline SEWA MENYEWA & $-0,03142$ \\
\hline \multicolumn{2}{|l|}{ ASSET TUNNELING: } \\
\hline 1 PEMBELIAN ASET (tunneling in) & $-0,03721$ \\
\hline PENJUALAN (tunneling out) & $-0,02639$ \\
\hline EQUITY TUNNELING & $-0,02701$ \\
\hline PROPPING & 0,00666 \\
\hline
\end{tabular}

Tabel 4 adalah hasil dari pengklasifikasian transaksi berdasarkan metode penilaian tunneling. Transaksi yang terindikasi cash flow tunneling antara lain penghapusan piutang berelasi (7 transaksi), jaminan piutang berelasi ( 8 transaksi), piutang berelasi (9 transaksi), pembayaran jasa berelasi (4 transaksi) dan sewa menyewa berelasi ( 2 transaksi). Transaksi yang terindikasi asset tunneling yaitu pembelian/ penjualan aset antar pihak berelasi berjumlah 25 transaksi. Equity tunneling berjumlah 3 transaksi. 
Tabel 4

Hasil Klasifikasi Transaksi berdasarkan Model Penilaian Tunneling

\begin{tabular}{|c|c|c|c|c|c|c|}
\hline & Transaksi & Jumlah & Persentase & $\begin{array}{l}\text { Skor } \\
\text { max }\end{array}$ & $\begin{array}{c}\text { Skor } \\
\text { min }\end{array}$ & Mean \\
\hline & FLOW & & & & & \\
\hline & VNELING : & & & & & \\
\hline 1 & $\begin{array}{l}\text { PENGHAPUSAN } \\
\text { PIUTANG }\end{array}$ & 7 & & & & \\
\hline 2 & PIUTANG & 9 & & & & \\
\hline 3 & $\begin{array}{l}\text { JAMINAN } \\
\text { PIUTANG }\end{array}$ & 8 & & & & \\
\hline 4 & $\begin{array}{l}\text { PEMBAYARAN } \\
\text { JASA }\end{array}$ & 4 & & & & \\
\hline 5 & SEWA MENYEWA & 2 & & & & \\
\hline & lah & 30 & $40,5 \%$ & 70 & 90 & 77 \\
\hline & ETT TUNNELING & & & & & \\
\hline 1 & $\begin{array}{l}\text { PEMBELIAN ASET } \\
\text { (tunneling in) }\end{array}$ & 7 & & & & \\
\hline 2 & $\begin{array}{l}\text { PENJUALAN } \\
\text { (tunneling out) }\end{array}$ & 18 & & & & \\
\hline & lah & 25 & $34 \%$ & 70 & 80 & 74 \\
\hline & UITY TUNNELING & 3 & $4 \%$ & 70 & 80 & 73 \\
\hline
\end{tabular}

\section{SIMPULAN}

Berdasarkan metode penilaian tunneling, transaksi yang dikategorikan sebagai cash flow tunneling sebanyak 40,5\%, aset tunneling sebanyak $34 \%$ dan equity tunneling sebanyak $4 \%$. Perusahaan yang mengumumkan transaksi berelasi yang terindikasi tunneling memperoleh abnormal return negatif pada saat pengumuman transaksi berelasi.

Pengungkapan transaksi berelasi diatur dalam PSAK No.7 tahun 2010. Pernyataan ini mensyaratkan pengungkapan hubungan, transaksi dan saldo pihak berelasi, termasuk komitmen dalam laporan keuangan. Kualitas pengungkapan merupakan hal yang penting sebagai dasar untuk pengambilan keputusan oleh pengguna laporan keuangan.

Pentingnya kualitas pengungkapan ini berkaitan dengan pemberian informasi kepada pihak lain dalam menilai besarnya konflik keagenan dalam perusahaan. Akan tetapi dalam praktiknya, pengungkapan transaksi berelasi dalam Laporan Keuangan sangat terbatas. Sebagai contoh, dalam kasus tunneling PT ED, pengguna laporan keuangan tidak memperoleh informasi yang cukup. berikut:

Pengungkapan transaksi berelasi di PT ED adalah sebagai

Pada bulan juni 2009, grup menandatangani perjanjian jual beli saham dan subrogasi untuk mengakuisi PT DTA dan PT DTI dari MM dengan jumlah transaksi AS\$0,8juta. Transaksi ini dikategorikan sebagai transaksi dengan perusahaan afiliasi karena Grup dan MM dikendalikan secara tidak langsung oleh pemegang saham yang sama. (catatan atas LK PT ED)

Informasi yang tercantum dalam catatan atas laporan keuangan di atas tidak memberikan informasi yang rinci mengenai hubungan antara perusahaan dengan pihak berelasi. Dalam catatan di atas, hanya dinyatakan bahwa grup dan MM dipegang secara langsung oleh pemegang saham yang sama, tanpa disertai struktur kepemilikan dan hubungan antara keduanya. Selain itu, uraian mengenai jumlah nominal transaksi tidak dilaporkan secara detail. Menurut data yang diperoleh dari laporan keterbukaan transaksi afiliasi dan benturan kepentingan dari Bapepam \& LK, total transaksi jual beli dan subrogasi yang disepakati sejumlah US\$886.013. Sejumlah US\$75.122 digunakan untuk membeli saham DTA dan DTI dan US\$810.891 digunakan untuk pelunasan hutang DTA dan DTI kepada MM. 
Fenomena di atas menunjukkan rendahnya kualitas pengungkapan mengenai transaksi berelasi. Kualitas pengungkapan menjadi hal yang penting berkaitan dengan pemberian informasi kepada pihak lain dalam menilai besarnya potensi konflik keagenan dalam perusahaan. Penelitian ini sekaligus sebagai dukungan dikeluarkanya PSAK No.7 tahun 2010 sebagai upaya peningkatan kualitas pengungkapan transaksi pihak berelasi.

\section{DAFTAR PUSTAKA}

Aharony, Joseph., Jiwei Wang and Hongqi Yuan. 2009. Tunneling as an Incentive for Earnings Management during the IPO Process in China. Journal Accounting Public Policy, 10: 125

Atanasov, Vadimir., Bernard Black and Conrad S. Ciccotelo. 2008. Unbundling Measuring Tunneling. Finance Working Paper. European Corporate Governance Institute.

Bae, Kee Hong, Jun Koo Kang and Jin Mo Kim. 2002. Tunneling or value added? Evidence from mergers by Korean business groups. Journal of Finance, 57: 2695-2740.

Baek, J.S., J.K. Kang and K.S. Park. 2004. Corporate Governance and Firm Value: Evidence from The Korean Financial Crisis. Journal of Financial Economics, 71: 265-313.

Baker, Richard E., Vadean C. Lembke and Thomas E. King. 2006. Advance Financial Accounting. McGraw-Hill.

Bertrand, Marianne, Paras Mehta and Sendhil Mullainathan. 2002. Ferreting out Tunneling: An application to Indian business groups. Quarterly Journal of Economics, 117:121-48.

Bradley, M., G.A. Jarrel and E.H. Kim. 1984. On The Existense of an Optimal Capital Structure: Theory and Evidence. Journal of Finance, 39: 857-878.
Brickley, James A., Ronald C. Lease and Clifford W. Smith, Jr. 1988. Ownership Structure and Voting on Antitakeover Amendments. Journal of Financial Economics, 20: 267-291.

Brockman, Paul and Dennis Y. Chung. 2003. Investor protection and firm liquidity. Journal of Finance, 58: 921-938.

Chen, Charles and Jaggi. 1998. The Association Between Independent Not Executive Directors, Family Control and Financial Disclosure. Working Paper. Departement of Accountancy, City University of Hongkong.

Cheung, Yan Leung., P. Raghavendra Rau and Aris Stouraitis. 2006. Tunneling, Propping and Expropriation: evidence from connected party transaction in Hongkong. Journal of Financial Economics, 82: 343-386.

Cheung, Yan Leung., Lihua Jing, Tong Lu, P. Raghavendra Rau and Aris Stouratis. 2009a. Tunneling and Propping up: An analysis of related party transaction by Chinese listed company. Pasific Basin Finance Journal, 17: 372-393.

Cheung, Yan-Leung.,Yuehua Qi, P. Raghavendra Rau and Aris Stouraitis. 2009b. Buy high, sell low: How listed firm price asset transfer in related party transaction. Journal of Banking and Finance, 33: 914-924.

Chung,K.S., \& Wong-Boren, A. (2000). Corporate Governance and Finance in East Asia: A Study of Indonesia, Republic of Korea, Malaysia, Philippines and Thailand. Vo.2, Asian Development Bank.

Claessens, Stijn., Siemon Djankov and Larry Lang. 2000a. The separation of ownership and control in East Asian Corporations. Journal of Financial Economics, 58: 81-112.

Claessens, Stijin, Siemon Djankov, Joseph Fan and Larry Lang. 2000b. Expropriation of Minority Shareholders: Evidence 
from East Asia. Policy Research Working Paper. The World Bank.

Cleassens, Stijn., Joseph P.H. Fan and Larry Lang. 2002a. The Benefit and Costs of Group Affiliation: Evidence from East Asia. Working Paper, Hongkong University of Science \& Technplogy and Chinese University of Hongkong.

Cleassens, Stijn., Siemon Djankov, Joseph P.H. Fan and Larry Lang. 2002b. Distengaling the incentive and entrenchment effect of large shareholding. Journal of Finance, 57: 27412771

Claessens, Stijn and Joseph P.H. Fan. 2003. Corporate governance in Asia: a survey. Working Paper. Universiteit van Amsterdam - Finance Group and Hong Kong University of Science and Technology.

Collins, D.W., E.L.Maydew and I.S. Weiss. 1997. Changes In The Value-Relevance of Earnings and Book Values Over The Past Forty Years. Journal of Accounting and Economics, 24: 39-67.

Cook, Karen S. 1977. Exchange and Power in Networks of Interorganizational Relations. Sociological Quaterly, 18: 6282

Desai, Mihir, I.J. Alexander Dyck and Luigi Zingales, 2007, Theft and Taxes, Journal of Financial Economics, forthcoming, at http://ssrn.com.

Djankov, Simeon., Rafael La Portal, Florencio Lopez-de-Silanes, and Andrei Shleifer. 2008. The law and economics of selfdealing. Journal of Financial Economics, 88, 430-465.

Eisenhardt,K. 1989. Agency Theory: An Assessment and Review. The Academy of Management Review, 14(1):57-74
Faccio, Mara and David Stolin. 2006. Expropriation vs Proportional Sharing in Corporate Acquisition. Journal of Business, 79: 1414-1444

Faccio, Mara., Larry Lang and Leslie Young. 2001. Dividends and Expropriation. American Economic Review, 91: 54-78.

Fama, E. And M. Jensen. 1983. Separation of Ownership and Control. Journal of Law and Economics, 26: 301-326.

Fan, Joseph P.H. and Vidhan K. Goyal. 2002. On The Patterns and Wealth Effects of Vertical Mergers. Working Paper. Hongkong University of Science \& Technology.

Fisman, Raymond and Tarun Khanna. 1998. Facilitating Development: The Role of Bussiness Groups. Workings Paper. Columbia Business School and Havard University.

Gilson, Ronald J. and Jeffrey N. Gordon. 2003. Controlling Controlling Shareholders.

Columbia Law School Working Paper No. 228.

Goranova, Maria. 2007. On The Both Side of The Deal: How Does Overlapping Institutional Ownership Affect Merger and Acquisition. Dissertation. Sofia University.

Gunarsih, Tri. 2002. Struktur Corporate Governance dan Kinerja Perusahaan: Pengaruh Struktur Kepemilikan dan Strategi Diversifikasi terhadap kinerja Perusahaan. Disertasi Doktor UGM Yogyakarta.

Hapsoro, Dody. 2006. Mekanisme Corporate Governance, Transaparansi dan Konsekuensi Ekonomik: Studi Empiris di Pasar Modal Indonesia. Disertasi Doktor UGM Yogyakarta.

Henry, D., H. Timmons and S. Rosenbush. 2002. Who else is hiding debt, moving financial obligations into off-book 
vehichles is now a common ploy. Business Week,January 28: 44-45

http://www.gatra.com/2007-09-05/versi_cetak.php?id=107452, diunduh 5 September 2007.

http://en.hukumonline.com/pages/lt4cc7fee3d6c95/bakrie-s-taxtroubles-the-kaltim-prima-coal-case, diunduh 27Oktober2010.

International Accounting Standards Committee. 2008. International Accounting Standard No.24 Related Party Disclosure

Ikatan akuntan Indonesia. 2010. Pernyataan Standar Akuntansi Keuangan No. 7 tentang Pengungkapan Pihak-pihak Berelasi.

Jensen, Michael C. 1986. Agency Costs of Free Cash Flow, Corporate Finance, and Takeovers. American Economic Review, 76: 323-329.

Jensen, Michael C. dan W.H Meckling. 1976. Theory of the Firm. Managerial Behavior, Agency Costs and Ownership Structure. Journal of Financial Economics, 3: 305-360.

Jian, Ming and T.J Wong. 2003. Earnings Management and Tunneling through Related Party Transactions: Evidence from Chinese Corporate Groups. Unpublished working paper. University of science and technology, Hongkong.

Johnson, Simon., Rafael La Porta, Florencio Lopez-de-Silanes, and Andrei Shleifer. 2000a. Tunneling. The American Economic Review, 90:22-27.

Johnson, Simon., Peter Boone, Alasdair Breach dan Eric Friedman.2000b.Corporate Governance in the Asian Financial Crisis. Journal of Financial Economics, 58: 141186.
Jones, J., 1991. Earnings Management during Impor Relief Investigations. Journal of Accounting Research, 29(2): 193228.

Keputusan BAPEPAM No 412/BL/2009 tentang Transaksi Afialiasi dan Benturan Kepentingan Tertentu.

Khanna, Tarun dan Krishna Palepu. 1997. Why Focused Strategy May be Wrong in Emerging Markets. Havard Business Review, 75(4): 41-51.

Khanna, Tarun, and Krishna Palepu, 2000. Is Group Membership Profitable in Emerging Markets? An Analysis of Diversified Indian Business Groups. Journal of Finance, LV: 867-891.

King, B.F. 1966. Market and Industry Factor in Stock Price Behaviour. Journal of Bussiness, 39: 139-189.

KPMG. 2010. KPMG's Corporate Tax Survey.

La Porta, R., Florencio Lopez-de-Silanes, Andrei Shleifer, and Robert W. Vishny. 1998. Law and Finance. Journal of Political Economy, 106 (December): 1113-1155.

La Porta, Rafael, Florencio Lopez-de-Silanes and Andrei Shleifer. 1999. Corporate Ownership Around the World. Journal of Finance, 54(2): 471-517.

La Porta, R., Florencio Lopez-de-Silanes, Andrei Shleifer, and Robert W. Vishny. 2000a. Agency Problems and Dividend Policies around the World. Journal of Finance ,55: 1-33.

La Porta, R., Florencio Lopez-de-Silanes, Andrei Shleifer, and Robert W. Vishny. 2000b. Investor Protection and Corporate Governance. Journal of Financial Economics 58, 3-27. 
La Porta, R., Florencio Lopez-de-Silanes, Andrei Shleifer, and Robert W. Vishny. 2002. Investor Protection and Corporate Valuation. Journal of Finance 57, 1147-1170.

Lemmon, Michael L., and Karl V. Lins. 2003. Ownership Structure, Corporate Governance and Firm Value: Evidence From The East Asian Financial Crisis. Journal of Finance, 58: $1445-1468$.

Mitton, T., 2002. A Cross-Firm Analysis The Impact of Corporate Governance on The East Asian Financial Crisis. Journal of Financial Economics, 64: 215-241

Na'im, Ainun. 2006. Special Purpose Vehicle Institution: Their Business and Accounting Implications. Gadjah Mada International Journal of Business, 8(1): 1-19

Nenova, T., 2000. The Value of Corporate Votes and Control Benefits: A Cross-Country Analysis. Unpublised Working Paper. Havard University.

Ohlson, J.A., 1995. Earnings, book values, and dividends in equity valuation. Contemporary Accounting Research 11, 661-687

Shin, H., and Y.S. Park. 1999. Financing Constraint and Internal Capital Market: Evidence from Korean Chaebols. Journal of Corporate Finance, 5: 169-194.

Shleifer, Andrei and Robert W. Vishny. 1994. Politicians and Firms. Quarterly Journal of Economics, 109: 995-1025.

Shleifer, Andrei dan Robert W. Vishny. 1997. A Survey of Corporate Governance. Journal of Finance, 52(2): 737-783

Stimpert, J.L., dan Irene M. Duhaime. 1997. Seeing The Big Picture: The Influence of Industry, Diversification and Business Strategy on Performance. Academy of Management Journal, 40(3): 560-583

\section{PENGEMBANGAN ALAT UKUR KESANTUNAN BAHASA INDONESIA DALAM INTERAKSI SOSIAL FORMAL BERSEMUKA}

\author{
Oleh: \\ Zamzani, Tadkiroatun Musfiroh, Siti Maslakhah, \\ Ari Listiyorini, dan Yayuk Eny Rahayu \\ Universitas Negeri Yogyakarta \\ email: zamzani_55@yahoo.com
}

\section{Abstrak}

Penelitian ini bertujuan (1) mengembangkan alat ukur kesantuanan bahasa Indonesia dalam tuturan formal bersemuka; (2) melakukan uji lapangan terbatas terhadap alat ukur kesantunan bahasa Indonesia dalam interaksi sosial formal bersemuka; (3) mengembangkan alat ukur kesantunan dalam bentuk VCD interaktif dengan program komputer. Adapun manfaat yang dapat dipetik adalah (1) acuan untuk mengukur kesopanan dalam bertindak tutur formal bersemuka, (2) gambaran alat ukur kesantunan formal bersemuka (3) acuan mengukur derajat kesantunan atau kesopanan pada pengguna bahasa Indonesia dalam berbagai kelas sosial.

Penelitian ini didasarkan pada empat alasan. Pertama, kesantunan berbahasa merupakan unsur penting dalam membina karakter positif masyarakat tutur Indonesia. Kedua, selalu ada potensi negatif dalam komunikasi lintas kultur dan lintas sosial karena belum ada alat ukur kesantunan dalam bahasa Indonesia. Ketiga, prinsip kesantunan berbahasa yang ada masih mengacu Barat yang belum tentu sesuai dengan kultur Indonesia. Keempat, alat ukur kesantunan dapat dimanfaatkan sebagai media pembina kesantunan berbahasa dalam berbagai ranah dan satuan pendidikan.

Sebagai pendekatannya, digunakan pendekatan riset dan pengembangannya atau Research and Development $(R \& D)$. Penelitian ini dilaksanakan selama tiga tahun. Pada penelitian tahun pertama telah dihasilkan indikator-indikator kesantunan berbahasa Indonesia. Pada penelitian tahun kedua dilakukan pengembangan alat ukur kesantunan yang didasarkan pada indikator keuniversalan konsep kesantunan masyarakat penutur bahasa Indonesia dalam situasi formal bersemuka 